thesis until Schneegans (Mém. Serv. Carte géol. France, 1938) suggested that the "Nappe du Flysch de l'Ubaye-Embrunais" in the French Alps has flowed forward like tar under the influence of gravity. He was shortly followed by Lugeon and Gagnebin, who, in a series of publications (particularly in 1941), demonstrated the importance of movement due to gravity both in the formation of the pre-Alps and among the Helvetic nappes. Despite these appeals to gravity, Lugeon and Gagnebin consider that gravitational sliding is not to be considered a substitute for the classical theories of mountain building -it is complementary to them.

Dr. Wilson went on to consider Gignoux's review (1948) of the subject (Bull. Soc. géol. France, 5, 18, 739). The latter appealed to the similarities between alpine structures and those seen in glaciers where gravity takes a predominant role. Gignoux also advocated the use of true-to-scale models as a means of appreciating the relation between structure and rock-movement. Such models should have true dynamic similarity, and it was felt that, by the use of such materials as soft wet clay for 'rocks', one would be able to "understand the real orogenic phenomena .... and perceive the nappes flowing by gravity" (Gignoux, 1948, loc. cit., 758).

Dr. F. M. Trotter spoke of the use of gravity determinations in the elucidation of concealed structures in north-western England. The results of the gravimeter work by the Anglo-Americal Oil Company have been published in the Quarterly Journal of the Geological Society. A detailed survey with numerous stations at short intervals has been recently completed over an area of some forty square miles of that part of the South Lancashire Coalfield which lies beneath New Red Rocks. Relative close-packing of isogams, interpreted as indicative of lines of faulting, shows in general a broad correspondence with known lines of major fracture. There are, however, exceptions, and at present it would be unwise to claim for this mothod too great a precision ; but the method is certainly useful in helping to determine sites at which deep borings for coal to depths of the order of 2,000-4,000 ft. would not be crossed by major faults.

\section{SUMMARY TABLES OF BIOLOGICAL TESTS}

T HE Chemical-Biological Coordination Center of the National Research Council of the United States has recently announced that the publication entitled "Summary Tables of Biological Tests"* is available free of charge. The Center was established in July 1946 to succeed the war-time Insect Control Committee, and like this latter body it functions by means of subcommittees dealing with various phases of its programme. Some idea of the scope of its activities is conveyed by enumeration of these subcommittees, which deal respectively with physical chemistry, biochemistry, organic chemistry, chemotherapy, entomology, malignancy, mammalogy, medicine, microbiology, veterinary medicine, physiology-pharmacology, plant sciences and sanitary engineering; there are also a chemical codification

* Summary Tables of Biological Tests. Sponsored by the ChemicalBiological Coordination Center. Vol. 1, No. 1, October. Pp. vi +58. Vol. 1, No. 2, December. Pp. vit,
National Research Council, 1949.) panel, a biological codification panel and an inorganic chemistry panel.

The objects of the Center are stated to be : (a) to assemble and organise data for the purpose of correlating chemical structure with biological activity, (b) to sponsor the preliminary screening of chemicals to determine their biological effects, and (c) to sponsor the preparation of reviews dealing with the correlation of chemical structure with biological activity. Financial support is provided by the American Cancer Society, the Department of the Army (Chemical Corps, Corps of Engineers, Quartermaster Corps, Surgeon-General's Office), the Department of the Navy (Office of Naval ResearchDivision of Medical Sciences) and the United States Public Health Service (National Cancer Institute). A system is in operation for soliciting materials and arranging for their testing.

The first two numbers of Vol. 1 of "Summary Tables of Biological Tests" contain fifty-eight and sixty-two pages respectively. Tables are arranged according to the type of test employed (for example, antibacterial, arachnidicide, fungicide, insecticide, plant growth regulator, insect and rat repellency, rodenticide, mammalian toxicity, antimalarial, brucellosis and cancer tests in No. 1, and the same plus snail control and rickettsia in No. 2), the test technique is described and the chemicals tested are listed alphabetically (Chemical Abstracts system) and their structural formulæ are reproduced.

From the first two numbers, it is clearly impossible to judge all the activities of the Coordination Center; but it can safely be said that every type of worker is likely to find within the pages of these "Summary Tables" collected information which will be of value to him in his studies, and for the publication of which he will have cause to be grateful to the National Research Council.

\section{KOSSUTH AWARDS IN HUNGARY FOR 1950}

K OSSUTH Awards in Hungary were first made in 1948 for outstanding work of a life-time, and in 1949 they were given for such achievements since the end of the Second World War. It has now been decided to make the Awards in recognition of outstanding work during the past year, and this practice will be continued in the future. Winners of the Awards for 1950 have recently been announced as follows, the value of the prizes being 10,000 forints except where otherwise stated.

Physics : the first prize (20,000 forints) jointly to Prof. P. Gombás for his work on the theory relating to the structure of noble metals and for his two books on atom physics, and to Prof. T. Neugebeuer for his achievements in electron-physics research.

Agricultural Science : Prof. R. Manninger $(20,000$ forints) for the discovery of a vaccine against swine erysipelas; K. Sedlmayer, plant improver, for the improvement of sugar beet, autumn barley, flax and vetches; and $L$. Kreybig, research director, for work on the drafting of a geological map of Hungary and his new method of applying artificial fertilizers.

Mathematics : Prof. L. Rédei (20,000 forints) for research in the theory of numbers and the theory of groups; Prof. L. Kalmár, for investigations in mathematical logic; and Prof. B. Szökefalvi-Nagy, for work on Hilbert space and Fourier series. 
Chemistry: Prof. T. Erdei-Gruz, for investigations of catalytic and corrosive processes ; Prof. G. Fodor, for work on the stereometric structure of organic compounds and for the synthesis of certain medicines ; and Prof. Z. Szabo, for work on the theory of the mechanism of reactions important to industry.

Medicine : Prof. G. Hetényi, for investigation of correlations between the brain and stomach ulcer; Prof. J. Szentágothai, for the investigation of correlations between the labyrinth and the action of the eye-muscles; I. Kemény, chief medical officer, for work in connexion with lower dentures prepared on the basis of anatomical and physiological investigations.

Technology: M. Freund, for the production of lubricating oils, washing powders and wax substitutes from Hungarian mineral oil ; Prof. J. Varga, for the conversion of Hungarian mineral oils into aromatic compounds; E. Winter, for work on the technology of radio waves; and Prof. G. Tarján and K. Martini, engineer, for work on the conversion of coal from the Komlo mines into coke.

Technical Reconstruction: K. P. Pfeiffer, engineer: (20,000 forints), for innovations in the methods of gasification of lignite and in gas generators; $\mathbf{A}$. Gerecs and J. Kolonics, chemists $(20,000$ forints jointly), the former for making possible the production of vitamin $\mathbf{P}$, vitamin $\mathbf{B}_{1}$, pyrocatechin, papaverin and $p$-amino-salicylic acid (for use in treating tuberculosis) from Hungarian raw materials, and the latter for important innovations in the production of 'ultraseptil' (sulphanyl drugs) and papaverin preparations ; L. M. Zsolnai, chemist, for the substitution of Hungarian raw materials for imported material for the manufacture of porcelain insulators; M. Fülöp, technician, for several innovations, one of which-spongy hard chromium plating-involves an annual saving of $1,700,000$ forints; L. Frank, foundry engineer, for his innovations in connexion with the casting of grey iron, which increased twofold the tensile strength of grey iron.

\section{U.S. NATIONAL ACADEMY OF SCIENCES}

\section{ANNUAL MEETING}

$\mathrm{T}$

HE National Academy of Sciences, at its annual meoting held in Washington, D.C., during April 24-26, elected the following officers, new members and foreign associates.

President for a four-year term ending in 1954 : Detlev W. Bronk, president of Johns Hopkins University and chairman of the United States National Research Council.

Foreign Secretary for a four-year term ending in 1954: Roger Adams, head of the Department of Chemistry, University of Illinois.

Members of the Council of the Academy, for a threeyear term ending in 1953: Oliver E. Buckley, president of the Bell Telephone Laboratories; and Walter S. Hunter, chairman of the Department of Psychology, Brown University.

New Members : Francis Birch, professor of geophysies, Harvard University ; S. Bochner, professor of mathematics, Princeton University; James Bonner, professor of biology, California Institute of Technology ; Ernst Cloos, professor of structural geology, Johns Hopkins University ; Lyman C. Craig, member of Rockefeller Institute for Medical Research, New
York ; Lester R. Dragstedt, chairman of the Department of Surgery, University of Chicago ; David R. Goddard, chairman of the Department of Botany, University of Pennsylvania; Herbert S. Harned, professor of chemistry, Yale University ; G. Evelyn Hutchinson, director of graduate studies in zoology, Yale University; M. R. Irwin, professor of genetics, University of Wisconsin ; E. C. Kendall, head of the Section on Biochemistry, Mayo Clinic, Rochester ; Gerard P. Kuiper, professor of astronomy, Yerkes Observatory, University of Chicago; W. F. Libby, professor, Institute for Nuclear Research, University of Chicago; Fritz A. Lipmann, head of the Biochemical Research Laboratory, Massachusetts General Hospital, Boston; R. Lorente de No, member of Rockefeller Institute for Medical Research, New York; Frank C. Mann, professor of experimental medicine, Mayo Foundation, University of Minnesota; Kenneth F. Maxcy, professor of epidemiology, School of Hygiene and Public Health, Johns Hopkins University ; C. E. Kenneth Mees, director and vicepresident in charge of research, Eastman Kodak Co., Rochester ; E. V. Murphree, president and director, Standard Oil Development Co., 15 West 5lst Street, New York; Alfred O. Nier, professor of physics, University of Minnesota ; Arthur E. Raymond, vicepresident and director, Douglas Aircraft Co., Inc., Santa Monica; Bruno B. Rossi, professor of physics, Massachusetts Institute of Technology; B. F. Skinner, professor of psychology, Harvard University ; J. A. Stratton, provost of the Massachusetts Institute of Technology; Victor C. Twitty, chairman of the Department of Zoology, Stanford University ; George Wald, professor of biology, Harvard University; Howel Williams, chairman of the Department of Geological Sciences, University of California ; Ralph E. Wilson, astronomer, Mount Wilson Observatory, Pasadena; Oskar Wintersteiner, head of the Division of Organic Chemistry, Squibb Institute for Medical Research, New Brunswick ; and M. L. Wolfrom, head of the Division of Organic Chemistry, Ohio State University.

Foreign Associates : C. H. Best, director of the Banting and Best Department of Medical Research, University of Toronto ; and A. J. Kluyver, professor of microbiology, Technical University of Delft.

\section{Medal Awards}

The Academy has made the following medal awards.

Henry Draper Gold Medal for 1949, to Prof. Otto Struve, Andrew MacLeish distinguished service professor and chairman of the Department of Astronomy, University of Chicago, in recognition of his contributions to astronomical physies, the most notable of which are his observations of stars with peculiar spectra and his development of theories of the structure of stellar atmospheres.

Daniel Giraud Elliot Gold Medal for 1946, to Dr. Robert Broom, keeper of vertebrate palæontology and anthropology, Transvaal Museum, in recognition of his many scientific articles and books, particularly his part in the book entitled "The South African Fossil Ape-Men, the Australopithecinæ", which was published in 1946.

Mary Clark Thompson Gold Medal for 1949, to Dr. Lauge Koch, of Copenhagen, for most important services to geology and palæontology, by his organisation and pursuit of exploration and geological studies in East Greenland, often under the most arduous conditions. 